\title{
Pontirhabdus pectinivorans gen. nov., sp. nov., isolated from seawater
}

Correspondence

Jongsik Chun

jchun@snu.ac.kr

\author{
Hana $\mathrm{Yi}_{1}{ }^{1}$ Jang-Cheon $\mathrm{Cho}^{2}$ and Jongsik Chun ${ }^{1,3}$
}

${ }^{1}$ Institute of Molecular Biology and Genetics, Seoul National University, 599 Kwanak-ro, Kwanak-gu, Seoul 151-742, Republic of Korea

${ }^{2}$ Division of Biology and Ocean Sciences, Inha University, Incheon 402-751, Republic of Korea

${ }^{3}$ School of Biological Sciences \& Institute of Bioinformatics (BIOMAX), Seoul National University, 599 Kwanak-ro, Kwanak-gu, Seoul 151-742, Republic of Korea

A yellow-coloured, rod-shaped, Gram-reaction-negative and aerobic bacterial strain, designated $\mathrm{JC} 2675^{\top}$, was isolated from a seawater sample from Jeju Island, Korea. The isolate required sea salts for growth. Gliding motility was observed. Flexirubin-type pigments were absent. Phylogenetic analyses based on $16 \mathrm{~S}$ rRNA gene sequences showed that strain $\mathrm{JC}_{2675^{\top}}$ represented a distinct phyletic line that reflected a novel generic status within the family Flavobacteraceae with relatively low gene sequence similarities $(<95.7 \%)$ to other recognized genera. The predominant isoprenoid quinone (MK-6) and DNA G+C content (30 mol\%) were consistent with the assignment of the novel strain to the family Flavobacteriaceae, but overall phenotypic traits demonstrated that the novel strain was not closely affiliated with any previously described genus. Based on data from a study using a polyphasic taxonomic approach, it is proposed that strain $\mathrm{JC} 2675^{\top}$ represents a new genus and novel species belonging to the family Flavobacteriaceae, for which the name Pontirhabdus pectinivorans gen. nov., sp. nov. is proposed. The type strain of the type species is $\mathrm{JC}_{2} 675^{\top}\left(=\mathrm{KACC} 14153^{\top}=\mathrm{JCM} 17107^{\top}\right)$.
At the time of writing, the bacterial family Flavobacteriaceae encompasses 87 genera with validly published names. Members of this family have diverse ecological niches and dynamic physiological features even within a genus (Bernardet \& Nakagawa, 2006). One of the major characteristics of this family is that most of its members are pigmented by carotenoid or flexirubin. The name Flavobacteriaceae was derived from the etymology of the type genus of this family, Flavobacterium, and means a yellow-coloured bacterium (L. adj. flavus, yellow; L. neut. n. bacterium, a small rod; N.L. neut. n. Flavobacterium, a yellow bacterium). An additional yellow-pigmented flavobacterial strain, designated $\mathrm{JC} 2675^{\mathrm{T}}$, was isolated from seawater and was studied according to the minimal standards for describing new taxa of the family Flavobacteriaceae (Bernardet et al., 2002). On the basis of evidence derived from a polyphasic taxonomic approach, the isolate represents a novel genus in the family Flavobacteriaceae.

Strain JC2675 ${ }^{\mathrm{T}}$ was isolated from a seawater sample from Jeju Island, Korea, using a standard dilution plating method on marine agar 2216 (MA; Difco). The isolate

The GenBank accession number for the 16S rRNA gene sequence of strain $\mathrm{JC} 2675^{\top}$ is $\mathrm{HM} 475134$.

Supplementary figures are available with the online version of this paper. was routinely cultured on MA and maintained as glycerol suspensions $(20 \%, \mathrm{w} / \mathrm{v})$ at $-80{ }^{\circ} \mathrm{C}$. Algibacter lectus KCTC $12103^{\mathrm{T}}$, Algibacter mikhailovii KCTC $12710^{\mathrm{T}}$, Lacinutrix copepodicola ACAM $1055^{\mathrm{T}}$, Lacinutrix algicola KCCM $42313^{\mathrm{T}}$ and Lacinutrix mariniflava KCCM $42306^{\mathrm{T}}$ were selected as reference strains and evaluated together under identical experimental conditions to those for strain JC2675 ${ }^{\mathrm{T}}$.

The 16S rRNA gene was enzymically amplified from a single colony. Primers, PCR conditions and sequencing methods have been described elsewhere (Chun \& Goodfellow, 1995). Preliminary sequence identification against the 16S rRNA gene sequences held in the EzTaxon database of prokaryotic type strains with validly published names (Chun et al., 2007) indicated that this isolate belonged to the family Flavobacteriaceae. The nearly complete 16S rRNA gene sequence of strain JC2675 ${ }^{\mathrm{T}}$ (1410 bp) was aligned manually against representatives of the family Flavobacteriaceae using the bacterial 16S rRNA secondary structure model (Woese et al., 1980). The regions available for all sequences (positions 93-182, 213820 and 850-1437; Escherichia coli numbering system) showed unambiguous alignment and were used to construct phylogenetic trees. Alignment and neighbourjoining tree (Saitou \& Nei, 1987) analyses were carried out using the jPHYDIT program (Jeon et al., 2005). An 
evolutionary distance matrix for the neighbour-joining tree was generated according to the model of Jukes \& Cantor (Jukes \& Cantor, 1969) and the resultant tree topologies were evaluated by bootstrap analyses (Felsenstein, 1985) based on 1000 resamplings. A Bayesian inference was performed with MrBayes 3.1.2 (Ronquist \& Huelsenbeck, 2003) with the General Time Reversible evolutionary model with a gamma-distributed rate variation. The program was run for 30000000 generations with a sample frequency of 100 and a burn-in of 100000 . A maximumlikelihood (Felsenstein, 1993) tree was constructed using PAUP 4.0 (Swofford, 1998) with a heuristic search option and 100 replicates. On the basis of $16 \mathrm{~S}$ rRNA gene sequence analyses, strain $\mathrm{JC} 2675^{\mathrm{T}}$ showed the highest sequence similarity to A. lectus KMM $3902^{\mathrm{T}}$ ( $95.6 \%$ ), followed by $A$. mikhailovii LMG $23988^{\mathrm{T}}$ (95.3\%), Gaetbulibacter saemankumensis SMK-12 ${ }^{\mathrm{T}}$ (94.8\%), Flaviramulus basaltis $\mathrm{H} 35^{\mathrm{T}}$ (94.5\%), L. copepodicola DJ3 ${ }^{\mathrm{T}}(94.4 \%)$, the genus Olleya (94.3-94.5\%), the genus Bizionia (93.8-94.2\%), L. algicola $\mathrm{AKS}_{293}{ }^{\mathrm{T}}(94.2 \%), \quad$ L. mariniflava $\mathrm{AKS}_{32}{ }^{\mathrm{T}}(94.0 \%)$, Gaetbulibacter marinus IMCC $1914^{\mathrm{T}}(93.6 \%)$ and Formosa algae KMM $3553^{\mathrm{T}}(93.3 \%)$. No other taxon showed more than $93 \%$ sequence similarity with the new isolate. Phylogenetic analysis revealed that strain JC2675 ${ }^{\mathrm{T}}$ could be clearly distinguished from any recognized genus (Fig. 1). Strain JC2675 ${ }^{\mathrm{T}}$ formed a distinct phyletic line within the radiation of the family Flavobacteriaceae and the branching position varied considerably depending on the tree-making algorithm used and the taxa included in the analyses. In the neighbour-joining tree containing the type strains of type species belonging to the family Flavobacteriaceae, the isolate was positioned between the genera Algibacter and Lacinutrix and appeared to be more related to the genus Algibacter than to the genus Lacinutrix (Fig. 1). However, when the number of taxa analysed together was enlarged by adding the type strains of additional species, the isolate was positioned far from the genus Algibacter and branched as a sister group of the genus Lacinutrix (see Supplementary Fig. S1a in IJSEM Online). In the maximum-likelihood (Supplementary Fig. S1b) and Bayesian trees (Supplementary Fig. S1c), the novel strain branched in the middle of the clade containing the genera Algibacter, Hyunsoonleella and Jejuia. Thus, based on the 16S rRNA gene sequence analyses, strain $\mathrm{JC} 2675^{\mathrm{T}}$ appeared to represent a new genus and a novel species belonging to the family Flavobacteriaceae.

Growth on seawater-supplemented bacterial media including cetrimide agar (Difco), MacConkey agar (Difco) and yeast extract-free ZoBell's agar (ZoBell, 1941) was tested. The temperature $(5,10,15,20,25,30,35,40,45$ and $50{ }^{\circ} \mathrm{C}$ ), $\mathrm{pH}$ (between $\mathrm{pH} 5$ and $\mathrm{pH}$ 10.5, with increments of $0.5 \mathrm{pH}$ units; adjusted with $10 \mathrm{M} \mathrm{KOH}$ or $\mathrm{HCl}$ ) and $\mathrm{NaCl}$ or sea salts (Sigma) concentration $[0,0.5,1,2,3,4,5$, $7,10,12,15$ and $20 \%(\mathrm{w} / \mathrm{v})]$ ranges for growth were determined using synthetic ZoBell medium. Growth under anaerobic and microaerophilic conditions was assessed using anaerobically prepared MA in an anaerobic chamber
(10\% $\mathrm{CO}_{2}, 10 \% \mathrm{H}_{2}, 80 \% \mathrm{~N}_{2}$; Sheldon Manufacturing) and CampyPak Plus systems $\left(5-15 \% \mathrm{O}_{2}\right.$ and 5-12\% $\mathrm{CO}_{2}$; $\mathrm{BBL})$.

Cellular morphology and motility were examined after growth on MA at $30{ }^{\circ} \mathrm{C}$ for 2 days by transmission electron and phase-contrast microscopy, respectively (see Supplementary Fig. S2 in IJSEM Online). Gliding motility was observed by direct phase-contrast microscopic examination of cells initially grown in marine broth 2216 (Difco) at $30{ }^{\circ} \mathrm{C}$ for 2 days and subsequently incubated for 16,48 , and $72 \mathrm{~h}$ on microscope slides coated with MA $(0.7 \%$ agar $)$, according to the method described by Bowman (2000). The presence of flexirubin-type pigments was determined by flooding the cell mass taken from agar plates with $20 \%(\mathrm{w} / \mathrm{v}) \mathrm{KOH}$ and confirmed by examining the bathychromatic shift of the absorbance spectrum of ethanol and alkaline-ethanol extracts of lysed cells (Weeks, 1981).

Standard physiological and biochemical tests were performed as described previously (Smibert \& Krieg, 1994). The ability of the novel strain to hydrolyse alginic acids $(0.5 \%$, Sigma), casein (5\% skimmed milk, Difco), microcrystalline cellulose $(0.5 \%$, Sigma), chitin $(0.5 \%$, Sigma), egg yolk (5\%, Oxoid), elastin (0.5\%, Sigma), pectin $(0.5 \%$, Sigma), starch $(0.2 \%$, Difco), Tween 20 ( $1 \%$, Sigma), Tween 40 (1\%, Junsei), Tween 60 ( $1 \%$, Junsei) and Tween 80 (1\%, Sigma) was tested using MA as the basal medium. Decomposition of adenine $(0.5 \%$, Sigma), hypoxanthine $(0.5 \%$, Sigma), L-tyrosine $(0.5 \%$, Sigma) and xanthine (0.4\%, Sigma) was tested using MA according to Gordon et al. (1974). Other enzymic activities were determined using the API 20NE, API 20E and API ZYM (bioMérieux) test kits. Acid production from carbohydrates was tested by using the API 50CH kit with $\mathrm{CHB} / \mathrm{E}$ medium (bioMérieux) supplemented with halfstrength seawater ( $4 \%$ sea salts in distilled water, Sigma). Utilization of carbohydrates as sole carbon source was tested using the API $50 \mathrm{CH}$ kit with AUX medium (bioMérieux) supplemented with half-strength seawater. The API kits were inoculated with a heavy bacterial suspension in half-strength artificial seawater and the data were recorded for up to five consecutive days.

The DNA G $+\mathrm{C}$ content was determined by the thermal denaturation method (Marmur \& Doty, 1962). Menaquinone was isolated from 3-day-old cells according to Minnikin et al. (1984) and analysed by HPLC (Waters) as described by Collins (1985). For fatty acid analysis, strain $\mathrm{JC} 2675^{\mathrm{T}}$ and the five reference strains were grown on MA at $30{ }^{\circ} \mathrm{C}$ (strain JC2675 $5^{\mathrm{T}}$ ), $25{ }^{\circ} \mathrm{C}$ (Algibacter strains) and $15{ }^{\circ} \mathrm{C}$ (Lacinutrix strains) for 3 days. Extraction of fatty acid methyl esters and separation by GC were performed by using the Instant FAME method of the Microbial Identification System (MIDI) version 6.1 and the RTSBA6 6.10 database. The fatty acids were iso- $\mathrm{C}_{15: 0} 3-\mathrm{OH}$ $(16.7 \%)$, iso- $\mathrm{C}_{15: 1} \mathrm{G}(14.7 \%)$, iso- $\mathrm{C}_{17: 0} 3-\mathrm{OH}(10.7 \%)$, anteiso- $\mathrm{C}_{15: 0}(7.7 \%)$, iso- $\mathrm{C}_{15: 0}(7.6 \%)$, iso- $\mathrm{C}_{16: 0} 3-\mathrm{OH}$ 


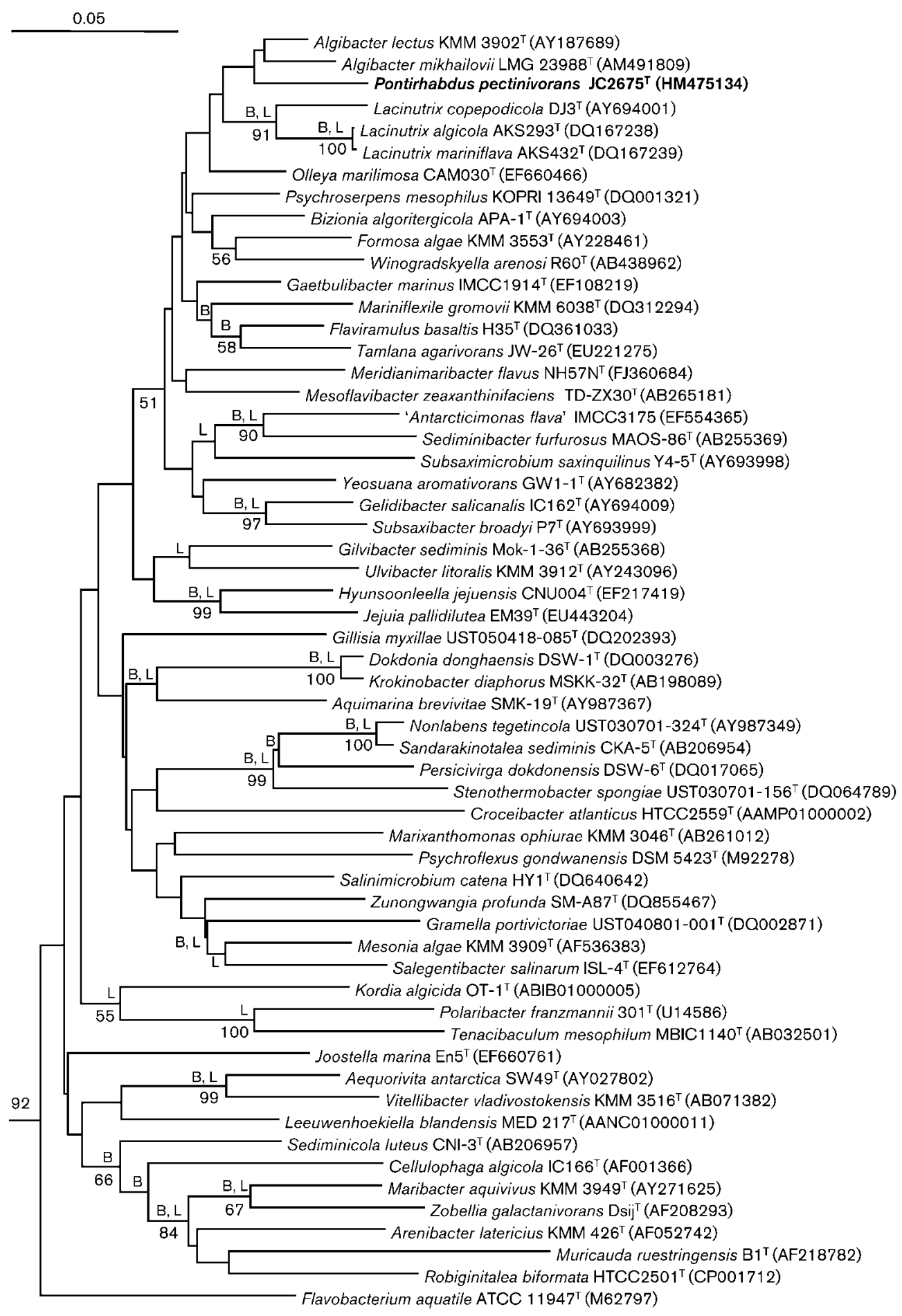

Fig. 1. Neighbour-joining tree based on a representative set of $16 \mathrm{~S}$ rRNA gene sequences of the family Flavobacteriaceae. The numbers at the nodes are percentages of bootstrap support (>50\%) from 1000 resampled datasets. Letters at the nodes indicate that the corresponding nodes (groupings) were recovered also in Bayesian (B) and/or in maximum-likelihood (L) treeinferring methods. Helicobacter pylori NCTC $11637^{\top}$ (GenBank no. Z25741) was used as an outgroup (not shown). Bar, $0.05 \mathrm{nt}$ substitution per position. 
Table 1. Characteristics that differentiate strain $\mathrm{JC} 2675^{\top}$ from other related genera in the family Flavobacteriaceae

Taxa: 1, Strain JC2675 ${ }^{\mathrm{T}}$ (data from this study); 2, Algibacter ( $n=2$; all data from this study except the DNA G + C content); 3 , Lacinutrix $(n=3$; all data from this study except the DNA G $+\mathrm{C}$ content); 4, Hyunsoonleella jejuensis CNU004 ${ }^{\mathrm{T}}$ (Yoon et al., 2010); 5, Jejuia pallidilutea EM39 ${ }^{\mathrm{T}}$ (Lee et al., 2009); 6, Olleya ( $n=2$; Lee et al., 2010; Nichols et al., 2005); 7, Flaviramulus basaltis $\mathrm{H}^{2} 5^{\mathrm{T}}$ (Einen \& Ovreås, 2006). $n$, Number of type strains in each genus; +, positive; -, negative; w, weakly positive; ND, no data available; v, varies among different strains within the same genus; VA, variable results depending on test methods; tr, trace. All taxa are aerobic and positive for catalase, alkaline phosphatase and hydrolysis of Tween 80 ; negative for nitrate reduction (not determined for F. basaltis). Strain $\mathrm{JC}_{2} 675^{\mathrm{T}}$ and members of the genera Algibacter and Lacinutrix are positive for leucine arylamidase, valine arylamidase, acid phosphatase and naphthol-AS-BI-phosphohydrolase activities; negative in tests for the decomposition of adenine, hypoxanthine or xanthine, the production of indole and activities of arginine dihydrolase, lysine decarboxylase, ornithine decarboxylase, tryptophan deaminase, lipase (C14), $\beta$-glucuronidase, $\beta$-glucosidase, $\alpha$-mannosidase and $\alpha$-fucosidase.

\begin{tabular}{|c|c|c|c|c|c|c|c|}
\hline Characteristic & 1 & 2 & 3 & 4 & 5 & 6 & 7 \\
\hline DNA G + C content $(\mathrm{mol} \%)$ & 30 & $31-35^{*}$ & $34.7-37^{\star}$ & 37.7 & 34.6 & $35-42$ & 31.4 \\
\hline \multicolumn{8}{|l|}{ Major fatty acids } \\
\hline ai- $\mathrm{C}_{15: 0}$ & 7.7 & $5.1-7.9$ & $5.4-14.2$ & 4.6 & 9.3 & $2.9-4.7$ & 6.2 \\
\hline $\mathrm{i}-\mathrm{C}_{15: 0}$ & 7.6 & $8.3-9.2$ & $11.1-16.6$ & 18.4 & 14.0 & $16.9-17.2$ & 19.4 \\
\hline $\mathrm{i}-\mathrm{C}_{15: 0} 3-\mathrm{OH}$ & 16.7 & $5.6-10.8$ & $3.2-12.6$ & 11.6 & 8.6 & $5.6-12.1$ & 13.6 \\
\hline $\mathrm{i}-\mathrm{C}_{15: 1}$ & 14.7 & $10.5-15.8$ & $12.3-15.2$ & 17.7 & 13.9 & $15.0-15.7$ & 21.2 \\
\hline $\mathrm{i}-\mathrm{C}_{16: 0} 3-\mathrm{OH}$ & 6.4 & $0.0-4.5$ & $7.3-10.4$ & 0.0 & 7.8 & $\operatorname{tr}-3.7$ & 4.5 \\
\hline $\mathrm{i}-\mathrm{C}_{17: 0} 3-\mathrm{OH}$ & 10.7 & $11.6-12.0$ & $5.6-13.0$ & 16.6 & 10.1 & $9.9-12.0$ & 13.3 \\
\hline Summed feature $3 \dagger$ & 3.3 & $8.2-29.6$ & $5.8-8.0$ & 5.0 & 5.4 & $8.9-9.9$ & 4.9 \\
\hline Requirement for sea salts $\ddagger$ & + & V & V & + & $\mathrm{ND}$ & - & + \\
\hline Requirement for yeast extract & - & - & - & $\mathrm{ND}$ & $\mathrm{ND}$ & + & + \\
\hline Flexirubin-type pigments & - & - & $\mathrm{v} \S$ & - & - & - & - \\
\hline Acid production from carbohydrates & + & + & $\mathrm{V}$ & $\mathrm{ND}$ & ND & + & + \\
\hline Acid production from glucose & - & - & - & - & $\mathrm{ND}$ & + & ND \\
\hline Gliding motility & + & $\mathrm{vll}$ & +9 & - & - & + & + \\
\hline Oxidase & + & + & + & + & + & + & - \\
\hline Urease & - & - & - & - & - & - & + \\
\hline Citrate utilization & - & - & $\mathrm{V}$ & ND & ND & + & ND \\
\hline Production of $\mathrm{H}_{2} \mathrm{~S}$ & - & - & - & - & $\mathrm{ND}$ & - & + \\
\hline Production of acetoin & + & + & + & + & ND & - & ND \\
\hline \multicolumn{8}{|l|}{ Degradation of: } \\
\hline Agar & - & + & - & - & ND & - & - \\
\hline Alginic acids & - & + & - & ND & $\mathrm{ND}$ & $\mathrm{ND}$ & ND \\
\hline Casein & - & - & + & - & - & + & ND \\
\hline Cellulose & - & - & - & + & - & - & - \\
\hline Chitin & - & - & - & ND & ND & ND & - \\
\hline Egg yolk & clear\# & clear & $\mathrm{V}$ & ND & ND & ND & ND \\
\hline Elastin & + & - & V & $\mathrm{ND}$ & ND & + & ND \\
\hline Aesculin & + & + & $\mathrm{V}$ & + & + & + & + \\
\hline Gelatin & + & VA & + & + & - & + & + \\
\hline Pectin & + & - & - & ND & ND & ND & ND \\
\hline Starch & - & + & $\mathrm{V}$ & - & + & $\mathrm{v}$ & + \\
\hline Tween 20 & + & $\mathrm{V}$ & + & $\mathrm{ND}$ & + & + & + \\
\hline Tween 40 & + & $\mathrm{V}$ & + & ND & $\mathrm{ND}$ & + & + \\
\hline Tween 60 & + & $\mathrm{V}$ & + & $\mathrm{ND}$ & ND & + & ND \\
\hline L-Tyrosine & + & + & + & $\mathrm{ND}$ & - & $\mathrm{V}$ & + \\
\hline \multicolumn{8}{|l|}{ API ZYM } \\
\hline Esterase (C4) & - & - & - & + & + & $\mathrm{V}$ & ND \\
\hline Esterase lipase (C8) & $\mathrm{w}$ & - & - & + & + & + & ND \\
\hline Cystine arylamidase & - & - & - & + & + & + & ND \\
\hline Trypsin & + & - & $\mathrm{V}$ & + & - & - & ND \\
\hline$\alpha$-Chymotrypsin & - & - & - & - & + & $\mathrm{V}$ & ND \\
\hline$\alpha$-Galactosidase & - & - & - & + & - & - & ND \\
\hline$\beta$-Galactosidase & - & $\mathrm{V}$ & - & + & - & - & ND \\
\hline
\end{tabular}


Table 1. cont.

\begin{tabular}{|llllllll|}
\hline Characteristic & $\mathbf{1}$ & $\mathbf{2}$ & $\mathbf{3}$ & $\mathbf{4}$ & $\mathbf{5}$ & $\mathbf{6}$ & $\mathbf{7}$ \\
\hline$\alpha$-Glucosidase & - & - & - & - & + & - \\
$N$-Acetyl- $\beta$-glucosaminidase & - & $\mathrm{V}$ & - & + & + & - & ND \\
\hline
\end{tabular}

${ }^{*}$ Data from (Bowman \& Nichols, 2005; Nedashkovskaya et al., 2004, 2007, 2008).

$\dagger$ Summed features are groups of two or three fatty acids that cannot be separated by GLC with the MIDI system. Summed feature 3 contained $\mathrm{C}_{16: 1} \omega 6 c$ and/or $\mathrm{C}_{16: 1} \omega 7 c$.

$\ddagger$ Strain ACAM $1055^{\mathrm{T}}$ cannot grow in the presence of $\mathrm{NaCl}$.

$\$$ L. copepodicola ACAM $1055^{\mathrm{T}}$ produced flexirubin-type pigments in this study, in contradiction to a previous report (Bowman \& Nichols, 2005). SA. mikhailovii KCTC $12710^{\mathrm{T}}$ did not show gliding motility, contrary to data from a previous report (Nedashkovskaya et al., 2007). IILacinutrix species were positive for gliding motility, in contradiction to previous reports (Bowman \& Nichols, 2005; Nedashkovskaya et al., 2008). \#Egg yolk decomposition was negative but a clear zone was formed around colonies.

(6.4\%), $\mathrm{C}_{15: 0} 3-\mathrm{OH}(5.0 \%)$, anteiso- $\mathrm{C}_{15: 1} \mathrm{~A}(3.6 \%)$, summed feature 3 [comprising $\mathrm{C}_{16: 1} \omega 6 c$ and/or $\mathrm{C}_{16: 1} \omega 7 c$ (3.3\%)], $\mathrm{C}_{16: 0} 3-\mathrm{OH}(2.8 \%), \mathrm{C}_{16: 0}(2.6 \%), \mathrm{C}_{17: 0} 2-\mathrm{OH}$ $(2.5 \%)$, iso- $\mathrm{C}_{13: 0}(2.2 \%), \mathrm{C}_{15: 0} 2-\mathrm{OH}(2.1 \%), \mathrm{C}_{15: 1} \omega 6 c$ $(2.1 \%)$, anteiso- $\mathrm{C}_{13: 0}(1.6 \%)$, iso- $\mathrm{C}_{14: 0}(1.4 \%), \mathrm{C}_{17: 0} 3-$ $\mathrm{OH}(1.1 \%)$ and $\mathrm{C}_{13: 0}(1.1 \%)$. The results of the morphological, cultural, biochemical, physiological and chemotaxonomic tests are presented in the species description.

Phylogenetic analyses based on the 16S rRNA gene sequences showed that $\mathrm{JC} 2675^{\mathrm{T}}$ represented a distinct phyletic line that reflected a novel genus status. Overall phenotypic traits also demonstrated that the novel strain was not closely affiliated with any previously described genera (Table 1). Thus, based on data derived using a polyphasic taxonomic approach, it is proposed that strain $\mathrm{JC} 2675^{\mathrm{T}}$ represents a new genus and a novel species belonging to the family Flavobacteriaceae, for which the name Pontirhabdus pectinivorans gen. nov., sp. nov. is proposed.

\section{Description of Pontirhabdus gen. nov.}

Pontirhabdus (Pon.ti.rhab'dus. L. n. pontus the sea; N.L. fem. n. rhabdus a rod, wand; N.L. fem. n. Pontirhabdus a rod that grows in the sea).

Gram-reaction-negative, oxidase- and catalase-positive and aerobic. Cells are rods with rounded ends and are able to glide. Spores are not formed. Produces non-diffusible carotenoid pigments, but flexirubin-type pigments are absent. Requires sea salts, but not yeast extract, for growth. Major isoprenoid quinone is MK-6. Predominant cellular fatty acids are iso- $\mathrm{C}_{15: 0} 3-\mathrm{OH}$, iso- $\mathrm{C}_{15: 1} \mathrm{G}$, iso- $\mathrm{C}_{17: 0}$ $3-\mathrm{OH}$, anteiso- $\mathrm{C}_{15: 0}$ and iso- $\mathrm{C}_{15: 0}$. DNA G $+\mathrm{C}$ content is $30 \mathrm{~mol} \%$. The maximum absorption peak of pigments is at $452 \mathrm{~nm}$ and the next shoulder peak is at $480 \mathrm{~nm}$. A member of the family Flavobacteriaceae, class Flavobacteria, phylum 'Bacteroidetes'. The type species is Pontirhabdus pectinivorans.

\section{Description of Pontirhabdus pectinivorans sp. nov.}

Pontirhabdus pectinivorans (pec.ti.ni.vo'rans. N.L. n. pectinum pectin; L. part. adj. vorans devouring; N.L. part. adj. pectinivorans pectin-devouring).

Displays the following characteristics in addition to those given for the genus. Grows under aerobic and microaerobic conditions, but not under anaerobic conditions. Cells are approximately $0.4-0.6 \times 1.0-2.4 \mu \mathrm{m}$. Colonies are yellow, convex, translucent, glistening, circular with entire margins. Glides on agar plates. Does not grow on cetrimide or MacConkey agar. Growth occurs at $\mathrm{pH}$ 5.5-8.5 (optimum, $\mathrm{pH} 7$ ) and $4-35{ }^{\circ} \mathrm{C}$ (optimum, $30{ }^{\circ} \mathrm{C}$ ). Requires sea salts concentration of $1-7 \%(\mathrm{w} / \mathrm{v})$ (optimum, 2-3\%) for growth and cannot grow on sea salts-free ZoBell's medium supplemented with $\mathrm{NaCl}$ only. Produces acetoin. Does not reduce nitrate to nitrite or nitrogen. Does not produce indole or $\mathrm{H}_{2} \mathrm{~S}$. Does not utilize citrate. Acid is not produced from glucose. Decomposes elastin, aesculin, gelatin, pectin, Tweens 20, 40, 60 and 80 and L-tyrosine, but not agar, adenine, alginic acids, casein, cellulose, chitin, egg yolk, hypoxanthine, starch or xanthine. Positive in tests for alkaline phosphatase, leucine arylamidase, valine arylamidase, trypsin, acid phosphatase and naphthol-ASBI-phosphohydrolase, and weakly positive for esterase lipase (C8), but negative for urease, arginine dihydrolase, lysine decarboxylase, ornithine decarboxylase, tryptophan deaminase, esterase (C4), lipase (C14), cystine arylamidase, $\alpha$-chymotrypsin, $\alpha$-galactosidase, $\beta$-glucuronidase, $\alpha$-glucosidase, $\beta$-glucosidase, $N$-acetyl- $\beta$-glucosaminidase, $\alpha$-mannosidase and $\alpha$-fucosidase. $\beta$-Galactosidase activity is negative in API ZYM and API 20E kits, but positive in the API 20NE kit. On the basis of the API 50CH system, utilizes the following carbohydrates as sole carbon source: D-xylose, D-galactose, D-mannose, salicin, cellobiose, maltose, lactose (bovine origin) and sucrose, but cannot utilize D-arabinose, D-glucose, D-fructose, methyl $\alpha$-D-mannopyranoside, methyl $\alpha$-D-glucopyranoside, $N$-acetylglucosamine, amygdalin, arbutin, aesculin ferric citrate, melibiose, trehalose, raffinose, starch, gentiobiose, methyl $\beta$-D-xylopyranoside, glycogen, 
turanose, glycerol, erythritol, L-arabinose, D-ribose, L-xylose, D-adonitol, L-sorbose, L-rhamnose, dulcitol, inositol, Dmannitol, D-sorbitol, inulin, melezitose, xylitol, D-lyxose, Dtagatose, D-fucose, L-fucose, D-arabitol, L-arabitol, potassium gluconate, potassium 2-ketogluconate or potassium 5ketogluconate. On the basis of the API $50 \mathrm{CH}$ system, is able to produce acid from D-xylose, D-galactose, D-glucose, Dmannose, L-rhamnose, amygdalin, aesculin ferric citrate, cellobiose, maltose, lactose (bovine origin), sucrose and gentiobiose. Produces acid weakly from D-fructose and salicin but no production from D-arabinose, methyl $\alpha$-D-mannopyranoside, methyl $\alpha$-D-glucopyranoside, $N$-acetylglucosamine, arbutin, melibiose, trehalose, raffinose, starch, methyl $\beta$-Dxylopyranoside, glycogen, turanose, glycerol, erythritol, Larabinose, D-ribose, L-xylose, D-adonitol, L-sorbose, dulcitol, inositol, D-mannitol, D-sorbitol, inulin, melezitose, xylitol, Dlyxose, D-tagatose, D-fucose, L-fucose, D-arabitol, L-arabitol, potassium gluconate, potassium 2-ketogluconate or potassium 5-ketogluconate. The fatty acids include iso- $\mathrm{C}_{15: 0} 3$ $\mathrm{OH}$, iso- $\mathrm{C}_{15: 1} \mathrm{G}$, iso- $\mathrm{C}_{17: 0} 3-\mathrm{OH}$, anteiso- $\mathrm{C}_{15: 0}$, iso- $\mathrm{C}_{15: 0}$, iso- $\mathrm{C}_{16: 0} \quad 3-\mathrm{OH}, \mathrm{C}_{15: 0} 3-\mathrm{OH}$, anteiso- $\mathrm{C}_{15: 1} \mathrm{~A}$, summed feature 3 (comprising $\mathrm{C}_{16: 1} \omega 6 c$ and/or $\mathrm{C}_{16: 1} \omega 7 c$ ), $\mathrm{C}_{16: 0} 3-$ $\mathrm{OH}, \mathrm{C}_{16: 0}, \mathrm{C}_{17: 0} 2-\mathrm{OH}$, iso- $\mathrm{C}_{13: 0}, \mathrm{C}_{15: 0} 2-\mathrm{OH}, \mathrm{C}_{15: 1} \omega 6 c$, anteiso- $\mathrm{C}_{13: 0}$, iso- $\mathrm{C}_{14: 0}, \mathrm{C}_{17: 0} 3-\mathrm{OH}$ and $\mathrm{C}_{13: 0}$.

The type strain, $\mathrm{JC}^{2675^{\mathrm{T}}}\left(=\mathrm{KACC} 14153^{\mathrm{T}}=\mathrm{JCM} 17107^{\mathrm{T}}\right)$, was isolated from a seawater sample from Jeju Island, Korea. The DNA G+C content of the type strain is $30 \mathrm{~mol} \%$.

\section{Acknowledgements}

We thank Dr J.-S. Lee for providing the Algibacter strains and Dr J. P. Bowman for providing the L. copepodicola ACAM $1055^{\mathrm{T}}$ strain used in this study. This work was supported by the Priority Research Centers Program (\#2008-005J00201) and National Research Foundation grant (\#2010-0017955) funded by the Korean government (MEST), by the project on survey and excavation of Korean indigenous species of the National Institute of Biological Resources (NIBR) under the Ministry of Environment, and by a grant from Regional SubGenBank Support Program of Rural Development Administration, Republic of Korea.

\section{References}

Bernardet, J. F. \& Nakagawa, Y. (2006). An introduction to the family Flavobacteriaceae. In The Prokaryotes, pp. 455-480. Edited by M. Dworkin, S. Falkow, E. Rosenberg, K.-H. Schleifer \& E. Stackebrandt. New York: Springer.

Bernardet, J. F., Nakagawa, Y., Holmes, B. \& Subcommittee on the taxonomy of Flavobacterium and Cytophaga-like bacteria of the International Committee on Systematics of Prokaryotes (2002). Proposed minimal standards for describing new taxa of the family Flavobacteriaceae and emended description of the family. Int J Syst Evol Microbiol 52, 1049-1070.

Bowman, J. P. (2000). Description of Cellulophaga algicola sp. nov., isolated from the surfaces of Antarctic algae, and reclassification of Cytophaga uliginosa (ZoBell and Upham 1944) Reichenbach 1989 as Cellulophaga uliginosa comb. nov. Int J Syst Evol Microbiol 50, 18611868.
Bowman, J. P. \& Nichols, D. S. (2005). Novel members of the family Flavobacteriaceae from Antarctic maritime habitats including Subsaximicrobium wynnwilliamsii gen. nov., sp. nov., Subsaximicrobium saxinquilinus sp. nov., Subsaxibacter broadyi gen. nov., sp. nov., Lacinutrix copepodicola gen. nov., sp. nov., and novel species of the genera Bizionia, Gelidibacter and Gillisia. Int J Syst Evol Microbiol 55, 1471-1486.

Chun, J. \& Goodfellow, M. (1995). A phylogenetic analysis of the genus Nocardia with 16S rRNA gene sequences. Int J Syst Bacteriol 45, 240-245.

Chun, J., Lee, J.-H., Jung, Y., Kim, M., Kim, S., Kim, B. K. \& Lim, Y. W. (2007). EzTaxon: a web-based tool for the identification of prokaryotes based on $16 \mathrm{~S}$ ribosomal RNA gene sequences. Int J Syst Evol Microbiol 57, 2259-2261.

Collins, M. D. (1985). Analysis of isoprenoid quinones. Methods Microbiol 18, 329-366.

Einen, J. \& Ovreås, L. (2006). Flaviramulus basaltis gen. nov., sp. nov., a novel member of the family Flavobacteriaceae isolated from seafloor basalt. Int J Syst Evol Microbiol 56, 2455-2461.

Felsenstein, J. (1985). Confidence limits on phylogenies: an approach using the bootstrap. Evolution 39, 783-791.

Felsenstein, J. (1993). PHYLIP (phylogenetic inference package) version 3.5.1. Distributed by the author. Department of Genome Sciences, University of Washington, Seattle, USA.

Gordon, R. E., Barnett, D. A., Handerhan, J. E. \& Pang, C. H.-N. (1974). Nocardia coeliaca, Nocardia autotrophica, and the nocardin strain. Int J Syst Bacteriol 24, 54-63.

Jeon, Y. S., Chung, H., Park, S., Hur, I., Lee, J. H. \& Chun, J. (2005). jPHYDIT: a JAVA-based integrated environment for molecular phylogeny of ribosomal RNA sequences. Bioinformatics 21, 31713173.

Jukes, T. H. \& Cantor, C. R. (1969). Evolution of protein molecules. In Mammalian Protein Metabolism, vol. 3, pp. 21-132. Edited by H. N. Munro. New York: Academic Press.

Lee, D. H., Kahng, H. Y., Lee, Y. S., Jung, J. S., Kim, J. M., Chung, B. S., Park, S. K. \& Jeon, C. O. (2009). Jejuia pallidilutea gen. nov., sp. nov., a new member of the family Flavobacteriaceae isolated from seawater. Int J Syst Evol Microbiol 59, 2148-2152.

Lee, S. Y., Park, S., Oh, T. K. \& Yoon, J. H. (2010). Description of Olleya aquimaris sp. nov., isolated from seawater, and emended description of the genus Olleya Mancuso Nichols et al. 2005. Int J Syst Evol Microbiol 60, 887-891.

Marmur, J. \& Doty, P. (1962). Determination of the base composition of deoxyribonucleic acid from its thermal denaturation temperature. J Mol Biol 5, 109-118.

Minnikin, D. E., O'Donnell, A. G., Goodfellow, M., Alderson, G., Athalye, M., Schaal, A. \& Parlett, J. H. (1984). An integrated procedure for the extraction of bacterial isoprenoid quinones and polar lipids. J Microbiol Methods 2, 233-241.

Nedashkovskaya, O. I., Kim, S. B., Han, S. K., Rhee, M. S., Lysenko, A. M., Rohde, M., Zhukova, N. V., Frolova, G. M., Mikhailov, V. V. \& Bae, K. S. (2004). Algibacter lectus gen. nov., sp. nov., a novel member of the family Flavobacteriaceae isolated from green algae. Int J Syst Evol Microbiol 54, 1257-1261.

Nedashkovskaya, O. I., Vancanneyt, M., Kim, S. B., Hoste, B. \& Bae, K. S. (2007). Algibacter mikhailovii sp. nov., a novel marine bacterium of the family Flavobacteriaceae, and emended description of the genus Algibacter. Int J Syst Evol Microbiol 57, 2147-2150.

Nedashkovskaya, O. I., Kwon, K. K., Yang, S. H., Lee, H. S., Chung, K. H. \& Kim, S. J. (2008). Lacinutrix algicola sp. nov. and Lacinutrix mariniflava sp. nov., two novel marine alga-associated bacteria and 
emended description of the genus Lacinutrix. Int J Syst Evol Microbiol 58, 2694-2698.

Nichols, C. M., Bowman, J. P. \& Guezennec, J. (2005). Olleya marilimosa gen. nov., sp. nov., an exopolysaccharide-producing marine bacterium from the family Flavobacteriaceae, isolated from the Southern Ocean. Int J Syst Evol Microbiol 55, 1557-1561.

Ronquist, F. \& Huelsenbeck, J. P. (2003). MrBayes 3: Bayesian phylogenetic inference under mixed models. Bioinformatics 19, 1572-1574.

Saitou, N. \& Nei, M. (1987). The neighbor-joining method: a new method for reconstructing phylogenetic trees. Mol Biol Evol 4, 406-425.

Smibert, R. M. \& Krieg, N. R. (1994). Phenotypic characterization. In Methods for General and Molecular Bacteriology, pp. 607-654. Edited by P. Gerhardt, R. G. E. Murray, W. A. Wood \& N. R. Krieg. Washington, DC: American Society for Microbiology.

Swofford, D. L. (1998). Phylogenetic analysis using parsimony (paup). Version 4. Sunderland, MA: Sinauer Associates.
Weeks, O. B. (1981). Preliminary studies of the pigments of Flavobacterium breve NCTC 11099 and Flavobacterium odoratum NCTC 11036. In The Flavobacterium-Cytophaga Group, pp. 108-114. Edited by H. Reichenbach \& O. B. Weeks. Weinheim: Gesellschaft fur Biotechnologische Forschung.

Woese, C. R., Magrum, L. J., Gupta, R., Siegel, R. B., Stahl, D. A., Kop, J., Crawford, N., Brosius, J., Gutell, R. \& other authors (1980). Secondary structure model for bacterial $16 \mathrm{~S}$ ribosomal RNA: phylogenetic, enzymatic and chemical evidence. Nucleic Acids Res 8, 2275-2293.

Yoon, B. J., Lee, D. H., Kang, B. J., Kahng, H. Y., Oh, Y. S., Sohn, J. H., Choi, E. S. \& Oh, D. C. (2010). Hyunsoonleella jejuensis gen. nov., sp. nov., a novel member of the family Flavobacteriaceae isolated from seawater. Int J Syst Evol Microbiol 60, 382-386.

ZoBell, C. E. (1941). Studies on marine bacteria. I. The cultural requirements of heterotrophic aerobes. J Mar Res 4, 42-75. 